\title{
An Evaluation of West and Central African Ports to Serve as a Hub on the Gulf of Guinea Container Ports Range
}

\author{
Balla Nguele Veronique, Youfang Huang \\ Scientific Research Academic of Shanghai Maritime University, Shanghai, China \\ Email: v.ballanguele@gmail.com, yhuang@shmtu.edu.cn
}

How to cite this paper: Veronique, B.N. and Huang, Y.F. (2019) An Evaluation of West and Central African Ports to Serve as a Hub on the Gulf of Guinea Container Ports Range. Open Journal of Applied Sciences, 9, 285-305.

https://doi.org/10.4236/ojapps.2019.94024

Received: April 1, 2019

Accepted: April 26, 2019

Published: April 29, 2019

Copyright (c) 2019 by author(s) and Scientific Research Publishing Inc. This work is licensed under the Creative Commons Attribution International License (CC BY 4.0).

http://creativecommons.org/licenses/by/4.0/

\begin{abstract}
The level of competitions among ports keep increasing as port worldwide keep upgrading and expanding their port infrastructures so as to capture the greater share of the market. Every continent phases these competitions. This phenomenon is more prominent in developed countries where ports do not only compete among regional ports but also compete with other ports within the same country such as in America, some European countries and part of Asia like in China. However, the situation is a bit different when it comes to African ports. Most African ports have poor infrastructures and limited technological investments and so port competitions in the African continent cannot be compared with that of the western ports. Despite these setbacks, there is a significant amount of competition among these African ports, especially on a regional basis. The aim of this paper is to determine which port can serve as a hub port between the West and Central African ports along the Gulf of Guinea. The method that will be used to evaluate these ports will be a port indexing method. This method considers different indices for port evaluation to determine the most suitable port. The port of Tema appeared as the most suitable port to serve as a hub port.
\end{abstract}

\section{Keywords}

Port Index, Hub Port, Competition, Transhipment, WCA, Network Optimization

\section{Introduction}

The maritime industry keeps evolving as the years go by and ports become more and more competitive. Ports keep trying to capture more markets by improving 
their efficiencies and effectiveness by providing state of the art infrastructures and high level of technology. This can be seen as some ports implement full automation in their terminals, especially when it comes to container terminals. One of the factors that have amounted to this, is the fact that more and more mega-large ships are being built every day which translates into port expansion activities being carried out by different ports to be able to accommodate these vessels. As the number of mega-ships increases so is the number of mega terminals [1]. This means that for a port to become a regional hub port, it should be able to not only accommodate these mega-ships but also provide efficient and effective services to ensure smooth operations to satisfy the various players in the industry. The characteristics of the mega terminal are somehow different from those of conventional terminals in terms of their sizes, draft, berth length and number, intermodal connectivity, and the level of value-added activities. The ability for ports to compete now lingers around these characteristics. Ports which can adopt have the power to attract bigger shipping companies and enhance their competitive position.

It is also important to note that one of the major factors that fuel intermodal transportation is Transshipment. The transhipment revolution has impacted the birth of new hub ports [1]. These hub ports which act as transhipment nodes are then linked to different modes of transport such as roads, rails and inland water-ways giving access to the hinterlands. The evolution of vessel sizes has indirectly led to the expansion of intermodal infrastructures. This phenomenon can be seen in China and in Europe as more roads and railways are being constructed to cater for the high traffic that is transshipped from their hub ports. The challenge when it comes to intermodal connectivity in most African countries is the poor state of modal infrastructures. Most of the roads are not paved which makes the roads unpassable during the raining season as the heavy rains damage the roads. Most railways are in a poor state due to lack of maintenance and some bare function.

This research seeks to evaluate some ports in West and Central Africa to determine which port has the capacity to serve as a hub port along the Gulf of Guinea. The method used to evaluate these ports is port indexation method. This method applies some of the indices that are used to evaluate ports. These indices include; port capacity index, port logistics index, governance index with other factors taken into consideration. The method applies keys activities and operations of the ports and the relationships between ports and their transportation networks are considered.

\section{Literature Review}

In order to accurately evaluate the potential of a hub port in a regional economy; it is imperative that the hub status of that port should be measured. Using existing port indices to evaluate a port status is one of the effective ways to determine the hub status of a port [2]. Ever since the introduction of containerization in the shipping industry, the geographical range of shipping services have been 
changed through the operations of the hub and spoke networks on a global scare making use of transhipment activities, connecting ports to the other modes of transport [2] [3]. Hub and spoke port practices also came into existence because of the evolution of the sizes of ships [4]. Some container ports in a feeder network act as the primary ports in logistics chains and inland networks while others ports that are pure transhipment ports in a shipping route might not be involved in hinterland connectivity [2]. Whenever the hub status of a port is evaluated, one of the most important indexes is to measure the accessibility of that port.

Most attempts that have been made to evaluate the accessibility of a port, always try to measure the ports connectivity to the hinterland [5]. However, accessibility evaluation is most appropriate when the connectivity of a single node is measured but is not suitable in a situation where a port has multiple transportation networks in a close proximity [2]. Therefore, port accessibility measurement will not be appropriate as an integral indicator for a container port hub status as supposed to port accessibility index by measuring a single transport mode. It will then be appropriate to note that, if a container port has multiplefunctions in an intermodal connectivity, measuring and indexing will be a more valuable method to evaluate the hub status of that port.

Other forms of measurements have been proposed to measure the accessibility of a port by Geurs and Ritsema van Eck (2001) [6] [7] which are as follows;

1) Infrastructure-based measures: The aim of this measure is to analyze the performance of a network in accordance with the condition of traffic demand. The important components in this measure refer to the level of accessibility and can be quantified as the average operating speed, the level of congestion, trip length and the travel time spent on a link.

2) Activity-based measures: This measure takes into account a location component and a transportation component. This measure is made up of some other sub-measures which include the following;

- Space-time measure which considers the accessibility from individual viewpoints, looking at time and space constraints. This accessibility measure looks at space-time geography and involves the determination of space-time prism showing the potential opportunities or areas that could be reached given individual constraints [6].

- Contour measures look at the different opportunities that can be achieved within a given travel time, distance and cost. The contour sizes are pre-defined by unit isochrones value specification for the variables of interest. All opportunities within an isochrones boundary are considered to be equally desirable with no differences considered.

- Balancing factor measures are factors that are based on spatial interaction constraints model proposed by Wilson (1971) [8], where the balancing factors ensure either that the magnitude of flows originating at zone $i$ equals the number of activities in zone $i$ or that the magnitude of flows destined at zone $j$ equals the number of activities in zone $j$. The balancing factors of this model can be interpreted as relative accessibility measures, modified to account for 
competition [6].

- Distance measure considers the degree to which two points or places are connected or the degree to which a point is connected different point within a particular study area. This measure is useful in situations where the destination is unknown and where connections are more important than travel time and distance.

- The gravity-base measure which considers the estimation of the accessibility of zone $I$ to all other zones $(n)$ in which shorter or longer distant opportunities provide diminishing influences. This uses the formula;

$$
A_{i}=\sum_{j} D_{j} F\left(C_{i j}\right)
$$

where $A_{i}$ measures the accessibility in zone $i$ to all opportunities $D$ in zone $j$ and $F\left(C_{i j}\right)$ is the impedance function, in which $C_{i j}$ represents the costs/resistance to travel between $I$ and $j$. The cost/impedance function influences the results of the accessibility measure significantly and takes a variety of different specifications.

3) Utility-based measures: This deals with economic benefit that is derived by people that have access to spatially distributed activities [9]. A utility-based measure considers accessibility as the outcome of a set of transport choices.

Analyses of port competitiveness are sometimes taken on the basis of individual characteristics or parameters or, alternatively, based on more aggregate holistic measures [10]. In an individual characteristic case, most investigations that involve port competition are based on comparing certain technical indicators such as productivity, pricing or efficiency. However, 'Physical and institutional factors have an effect on productivity to such an extent that it makes it very difficult to strictly compare any two or more terminals [11]. Also, it does not seem right to develop standards for terminal productivity on an international basis. Comparisons of terminals should be made carefully case-by-case. In contrast, holistic measures of port competitiveness cannot relysolely on easily quantifiable factors, for example, a port's technical efficiency to handle vessels and goods with costs or prices estimates. However, assessing port competitiveness should also involve other aspects that cannot be so easily quantified. Such factors should include; geographical location, trade patterns, government policies [6]. The reason why port competitiveness is measured is to determine its usefulness to shippers/carriers and also the potential utilization of port infrastructure. This tire with a definition of nodal accessibility that says, for a note to be attractive in a network, the mass and cost to reach other nodes via the network is taken into account. This encompasses both landward network connections to origin and destination nodes within a given port's hinterland, as well as to the prevailing seaward network defined by the container shipping that serves this port and links it to origin and destination nodes within the hinterlands of other ports worldwide.

All things being equal, the higher the accessibility of a container port, the more attractive it is to facilitate the transportation of goods, comparing it with other container ports within the relevant choice set of the decision-maker. This, therefore, means that to estimate a port's accessibility to other ports served by 
the global liner shipping network may be useful for providing a possible proxy characteristic for container port competitive evaluation. Since service frequency is one of the most desirable attributes of a container port, accessibility should clearly be a significant and influential attribute in any holistic assessment of port competitiveness.

\section{Methodology}

The method that is employed to evaluate the ports is the port indexation method. The evaluation is solely on container terminals. This evaluation method is adopted from Yong \& al [2] with some slight adjustments to suit the nature of the research. The different indices used include; port capacity index (handling capacity), port classification index (shipping network scale and inland network scale), and governance index, port demand forecasting, geographical locations. These are all the criteria's that will be used to evaluate the west and Central African ports. Container port inputs are made up of three important components: the container yard area, length of the berth and the handling capacity of the ports. The ports that are evaluated are ten and they include; Tema port (Ghana), Abidjan port (Ivory Coast), port of Dakar (Senegal), port of Lome (Togo), port of Cotonou (Benin), Lagos port complex Apapa (Nigeria), Douala port (Cameroon), Kribi port (Cameroon), port of Libreville (Gabon), port of Pointe-Noire (Congo).

\section{(A) Port classification index}

The port classification index is divided into Shipping network scale (continental, regional and feeder networks) and Inland network scale (roads, railways, inland waterways, airports, logistics zones).

\section{1) Shipping network Scale}

The Shipping Networks Scale considers the different categories of vessels and the mean of this scale will determine their scores.

a) Shipping Networks and Size of Ships

Our study is based on three categories of shipping networks: continental, regional, and feeder networks. The network potential of a container port is represented by these sizes of container ships and their slot capacity (Lam, 2011). The slot size of a container ship representative for each shipping network can be weight of a scale of shipping networks as shown in Table 1: Post-Panamax for a continental network; Panamax for a regional network; and around average size of container ships for a feeder shipping network.

b) Shipping Networks and scale for each network

The size ship can be used as a relative scale of each shipping network. If a container port has three shipping networks, then three sizes of container ships it can service by this container port. Therefore, the scale for shipping networks of each container port can be evaluated as in Table 2 and the Inland Networks and Scale of each Network ca be evaluated as in Table 3.

2) Inland Network Scale 
Table 1. Shipping networks and size of ships.

\begin{tabular}{cccc}
\hline $\begin{array}{c}\text { Item/Shipping } \\
\text { network }\end{array}$ & Continental network & Regional network & Feeder network \\
\hline $\begin{array}{c}\text { Type of } \\
\text { representative ship }\end{array}$ & Post-Panamax & Panamax & $\begin{array}{c}\text { Average of } \\
\text { container ships }\end{array}$ \\
Slot capacity & 8000 TEU & 4000 TEU & 2700 TEU \\
$\begin{array}{c}\text { Scale of } \\
\text { shipping network }\end{array}$ & $8000 / 14,700$ & $4000 / 14,700$ & $2700 / 14,700$ \\
\hline
\end{tabular}

Source: Compiled by V. Balla N. et al.

Table 2. Shipping networks and scale for each network.

\begin{tabular}{ccccc}
\hline Items & $\begin{array}{c}\text { Continental } \\
\text { network }\end{array}$ & $\begin{array}{c}\text { Regional } \\
\text { network }\end{array}$ & $\begin{array}{c}\text { Feeder } \\
\text { network }\end{array}$ & $\begin{array}{c}\text { Shipping } \\
\text { network Scale }\end{array}$ \\
\hline A port & $\sqrt{ }$ & $\sqrt{ }$ & $\sqrt{ }$ & $14,700 / 14,700$ \\
B port & $\sqrt{ }$ & $\sqrt{ }$ & & $(8000+4000) / 14,700$ \\
$\ldots$ & $\ldots$ & $\ldots$ & $\ldots$ & $\ldots$ \\
Pport & & & $\sqrt{ }$ & $2700 / 14,700$ \\
\hline
\end{tabular}

Source: Compiled by V. Balla N. et al.

Table 3. Inland networks and scale of each network.

\begin{tabular}{ccccccc}
\hline Port/Item & Road & $\begin{array}{c}\text { Freight } \\
\text { Railway }\end{array}$ & $\begin{array}{c}\text { Inland } \\
\text { waterway and/or } \\
\text { short sea shipping }\end{array}$ & $\begin{array}{c}\text { Logistics facilities } \\
\text { FTZ and/or } \\
\text { logistics park }\end{array}$ & $\begin{array}{c}\text { International } \\
\text { Airport }\end{array}$ & $\begin{array}{c}\text { Inland } \\
\text { network } \\
\text { scale }\end{array}$ \\
\hline A port & $\sqrt{ }$ & $\sqrt{ }$ & $\sqrt{ }$ & $\sqrt{ }$ & $\sqrt{ }$ & 1 \\
B port & $\sqrt{ }$ & $\sqrt{ }$ & $\sqrt{ }$ & $\sqrt{ }$ & 0.8 \\
C port & $\sqrt{ }$ & $\sqrt{ }$ & $\sqrt{ }$ & $\ldots$ & 0.6 \\
$\ldots$ & $\ldots$ & $\ldots$ & $\ldots$ & & $\ldots$ & $\ldots$ \\
Pport & $\sqrt{ }$ & $\ldots$ & & & & 0.2 \\
\hline
\end{tabular}

Source: Compiled V. Balla N. et al.

Evaluating the inland network scale will require us to consider the different transportation modes which include Roads, Railway, inland Waterways, International Airports and value-added services like Logistics Parks of free trade zones. Hence, determining the port classification index will involve summing up the mean of the shipping network index and the inland network index.

$$
P C I_{p}=\left(S S_{p}+I S_{p}\right) / 2
$$

where;

$P C I_{p}$ : classification sub-index for port $p, 0<P C I_{p} \leq 1$

$S S_{p}$ : shipping network scale of port $p, 0<S S_{p} \leq 1$

$I S_{p}$ : inland network scale of port $p, 0<I S_{p} \leq 1$

(B) Port Capacity Index: The port capacity index applied here is to evaluate 
the handling capacity of the ports and will be divided into sub-index $1 \& 2$. Sub-index 1 will evaluate the number of quayside cranes, length of berths, container yard capacity, operating time, berth draught. On the other hand, the sub-index evaluates any change in handling capacity of these ports (Table 4).

Where, $0<P S I_{p} \leq 1$.

For the port capacity sub-index 2, the aim is to evaluate the potential change of the handling capacity of the ports for 2015/2016. This is represented by;

$$
P S I 2_{p}(0.5) / C
$$

$$
C=\left(\text { Capacity }_{t-1} / \text { Capacity }_{t}\right)
$$

where,

Capacity: handling capacity of present year $t$,

Capacity $_{t-1}:$ handling capacity of previous year $t$,

$1 / 4 \leq P S Z_{p} \leq 1$

(C) Governance Index: The governance index considers the various governance practices by the governments of the different countries to determine the political status of all these countries. This evaluation makes use of the World Governance Index (WGI) and the data comes from the World Bank database [12]. The research makes use of some governance criteria's which include but not limited to:

- Government effective (Ge) which represent the degree of public and civil service quality.

- Rule of law (RL) which represents an agent's will to comply with societal rules, contract enforcement quality, property right, the police, the courts and the likelihood of riot and crime.

- Political stability (Ps) which represents the political status of the country.

- Regulatory quality $(\mathrm{Rq})$ which represents the quality of policies established by the government.

- Control of corruption (Cc) which represents the level of corruption within the country.

The means and variance of the percentile ranks of all the WGI will be used to determine the score for the Governance index.

Table 4. Evaluation scale of container terminal for port capacity sub-index 1 (PSI $1_{p}$ ).

\begin{tabular}{ccccccc}
\hline Port/Item & $\begin{array}{c}\text { Berth } \\
\text { Length } \\
\geq 366 \mathrm{~m}\end{array}$ & $\begin{array}{c}\text { Draft } \\
\geq 15 \mathrm{~m}\end{array}$ & $\begin{array}{c}\text { CY Density } \\
\geq 5000 \text { TEU }\end{array}$ & $\begin{array}{c}\text { Availability } \\
\text { Ship-shore-Cranes }\end{array}$ & $\begin{array}{c}24 / 7 \\
\text { Operating } \\
\text { Hours }\end{array}$ & $\begin{array}{c}\text { Total } \\
\text { Score }\end{array}$ \\
\hline Scale & 0.2 & 0.2 & 0.2 & 0.2 & 0.2 & \\
APort & $\sqrt{ }$ & $\sqrt{ }$ & $\sqrt{ }$ & $\sqrt{ }$ & $\sqrt{ }$ & 1 \\
B port & $\sqrt{ }$ & $\sqrt{ }$ & $\sqrt{ }$ & $\sqrt{ }$ & & 0.8 \\
C port & $\ldots$ & $\ldots$ & $\ldots$ & $\ldots$ & $\ldots$ & $\ldots$ \\
$\mathrm{N}^{\text {th }}$ Port & $\sqrt{ }$ & $\sqrt{ }$ & & & & 0.4 \\
\hline
\end{tabular}

Source : V. Balla N. et al. 
(D) Port Demand Forecasting: The port demand forecasting basically evaluates the capacity the port can handle in a given year to determine if it has the ability to handling a certain amount of traffic. A linear regression model is applied to evaluate the demand forecasting of the various ports. To be able to estimate $a_{T}$ and $b_{T}$, the linear regression model determines the regression line which best interpolates the $r$ most recent demand entries (i.e. $d_{T-r}+1, \cdots, b_{T-1}, d_{T}$ ):

$$
\begin{gathered}
b_{T}=\frac{-\frac{1}{2}(r-1) \sum_{k=0}^{r-1} d_{T-k}+\sum_{k=0}^{r-1} k d_{T-k}}{\frac{1}{4} r(r-1)^{2}-\frac{1}{6} r(r-1)(2 r-1)} \\
a_{T}=\frac{\sum_{k=0}^{r-1} d_{T-k}+\frac{1}{2} b_{T} r(r-1)}{r}
\end{gathered}
$$

where;

Let $d_{t}, t=1, T$, be the demand for the container throughput at time period $t$, where $T$ indicates the time period in correspondence of the latest container throughput entry available. Also, $a_{T}$ and $b_{T}$ represents y-intercept at period $t$ and the slope or trend of the regression respectively with $r$ being the number of periods of data and $k$ being an independent variable.

There are other evaluation parameters that were considered in this hub port evaluation and they include the GDP of the various countries, importation time and importation cost.

\section{Presentation of Data and Analysis}

The various port characteristics and dimensions are represented in the Table 5 below.

\begin{tabular}{|c|c|c|c|c|c|c|c|c|c|c|}
\hline $\begin{array}{l}\text { Container Yard } \\
\text { Capacity (TEU) }\end{array}$ & Tema & Abidjan & Dakar & Lome & Coutonou & $\begin{array}{l}\text { Lagos } \\
\text { (Apapa) }\end{array}$ & Douala & Kribi & Libreville & Pointe-Noire \\
\hline $\begin{array}{l}\text { Total Quay } \\
\text { Length (m) }\end{array}$ & 574 & 1 & 424 & 540 & 546 & 1,005 & 676 & 362 & 475 & 1,3 \\
\hline $\begin{array}{c}\text { No. of } \\
\text { Quayside Crane }\end{array}$ & 5 & 4 & 4 & 2 & 4 & 10 & 2 & 2 & 4 & 2 \\
\hline $\begin{array}{l}\text { No. of yard } \\
\text { Gantry Crane }\end{array}$ & 11 & 16 & 10 & 9 & 12 & 12 & 27 & 5 & - & 5 \\
\hline $\begin{array}{c}\text { No. of } \\
\text { reach stackers }\end{array}$ & 20 & 23 & 15 & 19 & 15 & 23 & 14 & 6 & 10 & 26 \\
\hline $\operatorname{Draft}(\mathrm{m})$ & 12.5 & 13 & 11 & 12 & 13.5 & 13.5 & 7 & 16 & 11 & 15 \\
\hline $\begin{array}{c}\text { No. of } \\
\text { Container Berth }\end{array}$ & 2 & 5 & 3 & 2 & - & 4 & 3 & 2 & 3 & 11 \\
\hline $\begin{array}{l}\text { Container Yard } \\
\text { Capacity (TEU) }\end{array}$ & 20 & 20 & 50 & 28,3 & 20 & 32 & 16,5 & 30 & 5,7 & 14,1 \\
\hline International Link & Road/rail & Road/rail & Road/rail & Road/rail & Road & Road/rail & Road/rail & Road & Road/rail & Road/rail \\
\hline Free Trade Zone & N/A & $\mathrm{N} / \mathrm{A}$ & N/A & N/A & N/A & - & N/A & $\mathrm{N} / \mathrm{A}$ & $\mathrm{N} / \mathrm{A}$ & N/A \\
\hline Operating Hours & $24 / 7$ & $24 / 7$ & $24 / 7$ & $24 / 7$ & $24 / 7$ & $24 / 7$ & $24 / 7$ & $24 / 7$ & $24 / 7$ & 24/ \\
\hline
\end{tabular}

Table 5. Port characteristic

Source: Compiled V.Balla N. et al. 


\section{(A) Port classification index}

\section{- Shipping network scale (Table 6)}

The aim of the shipping network scale is to evaluate the different capacity of ships that the ports can accommodate. The results show that Pointe-Noire and Kribi ports have the highest scale which means that they have the capacity to handle post Panamax vessels. While Tema, Abidjan, Lomé, Cotonou, Apapa ports have the ability to handle Panamax vessels with the least ports being Dakar, Douala and Libreville ports which means that these ports cannot accommodate bigger vessels.

\section{- Inland network scale (Table 7)}

The results from the inland network scale show that Tema and Pointe-Noire ports are linked to all the different mode of transportations that were considered making these ports the highest inland connected ports with the score of 1 while the other ports are not connected to one or two of the inland transportation modes (Table 8).

Table 6. Shipping network scale results

\begin{tabular}{ccccc}
\hline Items & $\begin{array}{c}\text { Continental } \\
\text { Network }\end{array}$ & $\begin{array}{c}\text { Regional } \\
\text { Network }\end{array}$ & $\begin{array}{c}\text { Feeder } \\
\text { Network }\end{array}$ & $\begin{array}{c}\text { Shipping } \\
\text { Network Scale }\end{array}$ \\
\hline Tema & & $\sqrt{ }$ & $\sqrt{ }$ & 0.4 \\
Abidjan & & $\sqrt{ }$ & $\sqrt{ }$ & 0.4 \\
Dakar & & $\sqrt{ }$ & $\sqrt{ }$ & 0.18 \\
Lomé & & $\sqrt{ }$ & $\sqrt{ }$ & 0.4 \\
Cotonou & $\sqrt{ }$ & $\sqrt{ }$ & $\sqrt{ }$ & 0.4 \\
Lagos (Apapa) & & & $\sqrt{ }$ & 0.4 \\
Douala & & $\sqrt{ }$ & $\sqrt{ }$ & 0.18 \\
Kribi & $\sqrt{ }$ & & & 0.18 \\
Libreville & & & & 1 \\
Pointe-Noire & & & & \\
\hline
\end{tabular}

Source: Compiled V. Balla N. et al.

Table 7. Results of inland network scale.

\begin{tabular}{ccccccc}
\hline Port & Road & Rail & Airport & Inland Waterway & Logistics Facilities & Scores \\
\hline Scale & 0.2 & 0.2 & 0.2 & 0.2 & 0.2 & \\
Tema & $\sqrt{ }$ & $\sqrt{ }$ & $\sqrt{ }$ & $\sqrt{ }$ & $\sqrt{ }$ & 1 \\
Abidjan & $\sqrt{ }$ & $\sqrt{ }$ & $\sqrt{ }$ & & $\sqrt{ }$ & 0.8 \\
Dakar & $\sqrt{ }$ & $\sqrt{ }$ & $\sqrt{ }$ & & $\sqrt{ }$ & 0.6 \\
Lome & $\sqrt{ }$ & $\sqrt{ }$ & $\sqrt{ }$ & $\sqrt{ }$ & 0.8 \\
Cotonou & $\sqrt{ }$ & $\sqrt{ }$ & $\sqrt{ }$ & & $\sqrt{ }$ & 0.8 \\
Lagos (Apapa) & $\sqrt{ }$ & $\sqrt{ }$ & $\sqrt{ }$ & & $\sqrt{ }$ & 0.8 \\
Douala & $\sqrt{ }$ & $\sqrt{ }$ & $\sqrt{ }$ & & $\sqrt{ }$ & 0.8 \\
Kribi & $\sqrt{ }$ & $\sqrt{ }$ & $\sqrt{ }$ & & $\sqrt{ }$ & 0.8 \\
Libreville & $\sqrt{ }$ & $\sqrt{ }$ & $\sqrt{ }$ & & $\sqrt{ }$ & 0.8 \\
Pointe-Noire & $\sqrt{ }$ & $\sqrt{ }$ & $\sqrt{ }$ & $\sqrt{ }$ & $\sqrt{ }$ & 1 \\
\hline
\end{tabular}

Source: Compiled V. Balla N. et al. 
Table 8. Final port classification score $(0.1-0.3)$.

\begin{tabular}{cccc}
\hline Port & Shipping Network & Inland Network & Total Score \\
\hline Tema & 0.2 & 0.3 & 0.5 \\
Abidjan & 0.2 & 0.2 & 0.4 \\
Dakar & 0.1 & 0.1 & 0.2 \\
Lomé & 0.2 & 0.2 & 0.2 \\
Coutonou & 0.2 & 0.2 & 0.4 \\
Apapa & 0.2 & 0.2 & 0.4 \\
Douala & 0.1 & 0.2 & 0.3 \\
Kribi & 0.3 & 0.2 & 0.5 \\
Libreville & 0.1 & 0.2 & 0.3 \\
Pointe-Noire & 0.3 & 0.2 & 0.5 \\
\hline
\end{tabular}

Source: Compiled V.Balla N. et al.

\section{(B) Port capacity index}

\section{- Sub-index 1 (Table 9)}

The results of the port capacity sub-index 1 show that the characteristics, dimensions, equipment and service level Pointe-Noire are higher than those of the other ports as Pointe-Noire has a score of 1 while the other ports have a score of 0.8 respectively. This gives Pointe-Noire an advantage over the different ports.

\section{- Sub-index 2 (Table 10)}

The results from the sub-capacity index 2 which considers the potentials of the various ports to handle port traffic in a case of an extreme expansion give Tema port the highest rating with Dakar, Abidjan, Libreville, Douala, PointeNoire, Cotonou, Lomé and Apapa respectively (Table 11).

(C) Governance index (Table 12)

Table 13 determines the final value for the governance index of the respective countries by calculating the mean, variance and standard deviation of the percentile ranks of the various countries.

The final results for the governance index entail awarding scores from 0.1 0.9 based on the means from Table 13 (Evaluation of governance index).

The final scores of the results for governance index are represented in Table 14.

The final governance index score shows that Ghana has the highest score which means the political status of the country is more stable than the other countries with Senegal and Togo, Benin, Gabon, Cote d'Ivoire, Cameroon, Nigeria and Congo respectively.

(D) Demand for container throughput (Table 15 and Table 16)

It is also important to determine the economic powers of the countries by considering their GPD. The economic activity of a country can influence the presence of a hub port. Table 17 shows the GPD's of the different countries in 2016 and their world ranking positions. 
Table 9. Results of PCI 1.

\begin{tabular}{|c|c|c|c|c|c|c|}
\hline $\begin{array}{l}\text { Container } \\
\text { Terminal }\end{array}$ & $\begin{array}{c}\text { Length of } \\
\text { Berth } \geq 366 \mathrm{~m}\end{array}$ & Draught $\geq 15$ & $\begin{array}{c}\text { CY } \\
\text { Density } \geq 5000 \\
\text { TEU }\end{array}$ & $\begin{array}{l}\text { Quayside } \\
\text { Cranes }\end{array}$ & $\begin{array}{c}\text { Operating } \\
\text { Hours } \\
(24 / 7)\end{array}$ & $\begin{array}{l}\text { Total } \\
\text { Score }\end{array}$ \\
\hline Tema & $\sqrt{ }$ & & $\sqrt{ }$ & $\sqrt{ }$ & $\sqrt{ }$ & 0.8 \\
\hline Abidjan & $\sqrt{ }$ & & $\sqrt{ }$ & $\sqrt{ }$ & $\sqrt{ }$ & 0.8 \\
\hline Dakar & $\sqrt{ }$ & & $\sqrt{ }$ & $\sqrt{ }$ & $\sqrt{ }$ & 0.8 \\
\hline Lomé & $\sqrt{ }$ & & $\sqrt{ }$ & $\sqrt{ }$ & $\sqrt{ }$ & 0.8 \\
\hline Cotonou & $\sqrt{ }$ & & $\sqrt{ }$ & $\sqrt{ }$ & $\sqrt{ }$ & 0.8 \\
\hline Lagos (Apapa) & $\sqrt{ }$ & & $\sqrt{ }$ & $\sqrt{ }$ & $\sqrt{ }$ & 0.8 \\
\hline Douala & $\sqrt{ }$ & & $\sqrt{ }$ & $\sqrt{ }$ & $\sqrt{ }$ & 0.8 \\
\hline Kribi & & $\sqrt{ }$ & $\sqrt{ }$ & $\sqrt{ }$ & $\sqrt{ }$ & 0.8 \\
\hline Libreville & $\sqrt{ }$ & & $\sqrt{ }$ & $\sqrt{ }$ & $\sqrt{ }$ & 0.8 \\
\hline Pointe-Noire & $\sqrt{ }$ & $\sqrt{ }$ & $\sqrt{ }$ & $\sqrt{ }$ & $\sqrt{ }$ & 1 \\
\hline
\end{tabular}

Source: Compiled V. Balla N. et al.

Table 10. Results of PCI 2.

\begin{tabular}{cc}
\hline Country & PSI 2 where, $1 / 4 \leq$ PSI $\leq 1$ \\
\hline Tema & 0.56678 \\
Abidjan & 0.50562 \\
Dakar & 0.51101 \\
Lomé & 0.47122 \\
Cotonou & 0.48121 \\
Lagos (Apapa) & 0.42839 \\
Douala & 0.48813 \\
Kribi & $\ldots \ldots \ldots .$. \\
Libreville & 0.49931 \\
Pointe-Noire & 0.48161 \\
\hline
\end{tabular}

Source: Compiled V. Balla N. et al.

Table 11. Final scores for port capacity index.

\begin{tabular}{cccc}
\hline PORTS & PCI 1 & PCI 2 & TOTAL SCORE \\
\hline Tema & 0.1 & 1 & 1.1 \\
Abidjan & 0.1 & 0.7 & 0.8 \\
Dakar & 0.1 & 0.8 & 0.9 \\
Lomé & 0.1 & 0.2 & 0.3 \\
Coutonou & 0.1 & 0.3 & 0.4 \\
Lagos (Apapa) & 0.1 & 0.1 & 0.2 \\
Douala & 0.1 & 0.5 & 0.6 \\
Kribi & 0.1 & $\ldots .$. & 0.1 \\
Libreville & 0.1 & 0.6 & 0.7 \\
Pointe-Noire & 0.2 & 0.4 & 0.6 \\
\hline
\end{tabular}

Source: Compiled V. Balla N. et al. 
Table 12. Governance index data of all the countries.

\begin{tabular}{|c|c|c|c|c|c|c|}
\hline BENIN & & 2012 & 2013 & 2014 & 2015 & 2016 \\
\hline \multirow[t]{3}{*}{ Control of corruption } & Estimate & -0.9 & -0.7 & -0.7 & -0.6 & -0.5 \\
\hline & Percentage Error & 20.9 & 24.6 & 29.8 & 33.2 & 36.5 \\
\hline & Standard Error & 0.2 & 0.2 & 0.2 & 0.2 & 0.2 \\
\hline \multirow[t]{3}{*}{ Government Effectiveness } & Estimate & -0.5 & -0.5 & -0.5 & -0.6 & -0.6 \\
\hline & Percentage Error & 36.5 & 37.0 & 36.1 & 29.8 & 33.2 \\
\hline & Standard Error & 0.2 & 0.2 & 0.2 & 0.2 & 0.2 \\
\hline \multirow[t]{3}{*}{ Political Stability } & Estimate & 0.4 & 0.3 & 0.0 & 0.0 & 0.1 \\
\hline & Percentile Rank & 58.3 & 58.3 & 47.1 & 45.2 & 48.6 \\
\hline & Standard Error & 0.2 & 0.2 & 0.2 & 0.2 & 0.2 \\
\hline \multirow[t]{3}{*}{ Regulatory Quality } & Estimate & -0.4 & -0.4 & -0.6 & -0.6 & -0.5 \\
\hline & Percentile Rank & 38.9 & 37.4 & 31.3 & 30.8 & 30.3 \\
\hline & Standard Error & 0.2 & 0.2 & 0.2 & 0.2 & 0.2 \\
\hline \multirow[t]{3}{*}{ Rule of Law } & Estimate & -0.6 & -0.6 & -0.5 & -0.5 & -0.7 \\
\hline & Percentile Rank & 33.3 & 34.3 & 36.1 & 33.7 & 29.3 \\
\hline & Standard Error & 0.1 & 0.1 & 0.2 & 0.1 & 0.2 \\
\hline \multicolumn{7}{|l|}{ CAMEROON } \\
\hline \multirow[t]{3}{*}{ Control of corruption } & Estimate & -1.2 & -1.1 & -1.2 & -1.1 & -0.1 \\
\hline & Percentile rank & 10.6 & 13.0 & 10.6 & 13.0 & 11.1 \\
\hline & Standard error & 0.1 & 0.1 & 0.1 & 0.1 & 0.1 \\
\hline \multirow[t]{3}{*}{ Government Effectiveness } & Estimate & -0.8 & -0.8 & -0.8 & -0.8 & -0.8 \\
\hline & Percentile rank & 21.66 & 21.6 & 21.6 & 21.6 & 22.1 \\
\hline & Standard error & 0.2 & 0.2 & 0.2 & 0.2 & 0.2 \\
\hline \multirow[t]{3}{*}{ Political stability } & Estimate & -0 & -0.5 & -1.1 & -1.0 & -0.9 \\
\hline & Percentile rank & 26. & 27.5 & 12.4 & 15.2 & 14.8 \\
\hline & Standard error & 0.2 & 0.2 & 0.2 & 0.2 & 0.2 \\
\hline \multirow[t]{3}{*}{ Regulatory Quality } & Estimate & -0.9 & -0.9 & -0.9 & -0.9 & -0.8 \\
\hline & Percentile rank & 21.3 & 19.0 & 19.7 & 16.8 & 23.1 \\
\hline & Standard error & 0.2 & 0.2 & 0.2 & 0.2 & 0.2 \\
\hline \multirow[t]{3}{*}{ Rule of Law } & Estimate & -0.1 & -1.1 & -0.9 & -0.9 & -1.0 \\
\hline & Percentile rank & 15.5 & 14.6 & 19.7 & 16.8 & 15.4 \\
\hline & Standard error & 0.1 & 0.1 & 0.2 & 0.2 & 0.1 \\
\hline CONGO REPUBLIC & & & & & & \\
\hline
\end{tabular}




\section{Continued}

\begin{tabular}{|c|c|c|c|c|c|c|}
\hline \multirow[t]{3}{*}{ Control of corruption } & Estimate & -1.2 & -1.2 & -1.2 & -1.2 & -1.2 \\
\hline & Percentile rank & 10.4 & 10.9 & 10.1 & 10.6 & 9.6 \\
\hline & Standard error & 0.2 & 0.2 & 0.2 & 0.2 & 0.2 \\
\hline \multirow[t]{3}{*}{ Government effectiveness } & Estimate & -1.2 & -1.2 & -1.1 & -1.0 & -1.1 \\
\hline & Percentile rank & 11.4 & 12.8 & 14.4 & 14.9 & 12.0 \\
\hline & Standard error & 0.2 & 0.2 & 0.2 & 0.2 & 0.2 \\
\hline \multirow[t]{3}{*}{ Political stability } & Estimate & -0.5 & -0.5 & -0.4 & -0.5 & -0.6 \\
\hline & Percentile error & 31.3 & 29.9 & 31.0 & 26.7 & 25.2 \\
\hline & Standard error & 0.2 & 0.2 & 0.2 & 0.2 & 0.2 \\
\hline \multirow[t]{3}{*}{ Regulatory quality } & Estimate & -1.4 & -1.3 & -1.2 & -1.2 & -1.2 \\
\hline & Percentile rank & 8.1 & 8.1 & 9.6 & 10.1 & 10.2 \\
\hline & Standard error & 0.2 & 0.2 & 0.2 & 0.2 & 0.2 \\
\hline \multirow[t]{3}{*}{ Rule of Law } & Estimate & -1.1 & -1.1 & -1.1 & -1.1 & -1.4 \\
\hline & Percentile rank & 12.7 & 11.5 & 13.0 & 14.4 & 12.7 \\
\hline & Standard error & 0.1 & 0.1 & 0.1 & 0.2 & 0.2 \\
\hline \multicolumn{7}{|l|}{ COTE D'IVOIRE } \\
\hline \multirow[t]{3}{*}{ Control of corruption } & Estimate & -0.4 & -0.4 & -0.4 & -0.4 & -0.5 \\
\hline & Percentile rank & 42.3 & 41.3 & 42.3 & 41.3 & 33.7 \\
\hline & Standard error & 0.1 & 0.1 & 0.1 & 0.1 & 0.1 \\
\hline \multirow[t]{3}{*}{ Government effectiveness } & Estimate & -0.8 & -0.7 & -0.8 & -0.7 & -0.7 \\
\hline & Percentile rank & 19.7 & 26.4 & 19.7 & 26.4 & 26.9 \\
\hline & Standard error & 0.2 & 0.2 & 0.2 & 0.2 & 0.2 \\
\hline \multirow[t]{3}{*}{ Political stability } & Estimate & -1.3 & -1.0 & -1.0 & -0.8 & -0.9 \\
\hline & Percentile rank & 11.8 & 17.1 & 13.3 & 20.0 & 16.2 \\
\hline & Standard error & 0.2 & 0.2 & 0.2 & 0.2 & 0.2 \\
\hline \multirow[t]{3}{*}{ Regulatory quality } & Estimate & -0.8 & -0.7 & -0.6 & -0.5 & -0.4 \\
\hline & Percentile rank & 24.6 & 24.6 & 30.3 & 34.1 & 39.9 \\
\hline & Standard error & 0.2 & 0.2 & 0.2 & 0.2 & 0.2 \\
\hline \multirow[t]{3}{*}{ Rule of Law } & Estimate & -1.1 & -0.9 & -0.6 & -0.6 & -0.7 \\
\hline & Percentile rank & 14.6 & 19.7 & 32.7 & 30.8 & 28.4 \\
\hline & Standard error & 0.1 & 0.1 & 0.1 & 0.1 & 0.1 \\
\hline \multicolumn{7}{|l|}{ GABON } \\
\hline \multirow[t]{3}{*}{ Control of corruption } & Estimate & -0.7 & -0.7 & $-0-7$ & -0.7 & -0.7 \\
\hline & Percentile rank & 28.4 & 29.4 & 28.4 & 26.4 & 24.5 \\
\hline & Standard error & 0.2 & 0.2 & 0.2 & 0.2 & 0.2 \\
\hline \multirow[t]{3}{*}{ Government effectiveness } & Estimate & -0.9 & -0.8 & -0.6 & -0.7 & -0.8 \\
\hline & Percentile rank & 19.4 & 22.3 & 26.9 & 23.6 & 20.7 \\
\hline & Standard error & 0.2 & 0.2 & 0.2 & 0.2 & 0.2 \\
\hline
\end{tabular}




\section{Continued}

\begin{tabular}{|c|c|c|c|c|c|c|}
\hline \multirow[t]{3}{*}{ Political stability } & Estimate & 0.3 & 0.3 & 0.1 & 0.0 & -0.1 \\
\hline & Percentile rank & 56.9 & 58.8 & 51.9 & 47.6 & 43.8 \\
\hline & Standard error & 0.2 & 0.2 & 0.2 & 0.2 & 0.2 \\
\hline \multirow[t]{3}{*}{ Regulatory quality } & Estimate & -0.6 & -0.6 & -0.8 & -0.8 & -0.8 \\
\hline & Percentile rank & 30.8 & 28.9 & 26.0 & 25.0 & 21.6 \\
\hline & Standard error & 0.2 & 0.2 & 0.2 & 0.2 & 0.2 \\
\hline \multirow[t]{3}{*}{ Rule of Law } & Estimate & -0.5 & -0.5 & -0.5 & -0.5 & -0.6 \\
\hline & Percentile rank & 40.8 & 36.2 & 35.1 & 33.2 & 31.3 \\
\hline & Standard error & 0.1 & 0.1 & 0.1 & 0.1 & 0.2 \\
\hline \multicolumn{7}{|l|}{ GHANA } \\
\hline \multirow[t]{3}{*}{ Control of corruption } & Estimate & -0.1 & -0.1 & -0.2 & -0.2 & -0.2 \\
\hline & Percentile rank & 55.0 & 55.5 & 52.4 & 52.9 & 50.1 \\
\hline & Standard error & 0.1 & 0.1 & 0.1 & 0.1 & 0.1 \\
\hline \multirow[t]{6}{*}{ Government effectiveness } & Estimate & 0.0 & -0.1 & -0.3 & -0.3 & -0.2 \\
\hline & Percentile rank & 53.1 & 50.2 & 43.8 & 45.2 & 46.2 \\
\hline & Standard error & 0.2 & 0.2 & 0.2 & 0.2 & 0.2 \\
\hline & Estimate & 0.1 & 0.1 & -0.1 & 0.0 & -0.2 \\
\hline & Percentile rank & 50.7 & 47.9 & 41.4 & 44.3 & 40.0 \\
\hline & Standard estimate & 0.2 & 0.2 & 0.2 & 0.2 & 0.2 \\
\hline \multirow[t]{3}{*}{ Regulatory quality } & Estimate & 0.1 & 0.1 & 0.0 & 0.0 & -0.2 \\
\hline & Percentile rank & 56.4 & 55.5 & 53.4 & 53.8 & 45.7 \\
\hline & Standard error & 0.2 & 0.2 & 0.2 & 0.2 & 0.2 \\
\hline \multirow[t]{3}{*}{ Rule of Law } & Estimate & 0.0 & 0.1 & 0.1 & 0.1 & 0.0 \\
\hline & Percentile rank & 55.9 & 58.2 & 60.1 & 60.6 & 54.8 \\
\hline & Standard error & 0.1 & 0.1 & 0.1 & 0.1 & 0.1 \\
\hline \multicolumn{7}{|l|}{ NIGERIA } \\
\hline \multirow[t]{3}{*}{ Control of corruption } & Estimate & -1.2 & -1.2 & -1.3 & -1.1 & -1.0 \\
\hline & Percentile rank & 10.9 & 9.5 & 8.2 & 12.5 & 13.5 \\
\hline & Standard error & 0.1 & 0.1 & 0.1 & 0.1 & 0.1 \\
\hline \multirow[t]{3}{*}{ Government effectiveness } & Estimate & -1.0 & -1.0 & -1.2 & -1.0 & -1.1 \\
\hline & Percentile rank & 16.6 & 16.6 & 12.0 & 16.3 & 12.5 \\
\hline & Standard error & 0.2 & 0.2 & 0.2 & 0.2 & 0.2 \\
\hline \multirow[t]{3}{*}{ Political stability } & Estimate & -2.0 & -2.1 & -2.1 & -1.9 & -1.9 \\
\hline & Percentile rank & 3.3 & 3.8 & 5.2 & 6.2 & 6.7 \\
\hline & Standard error & 0.2 & 0.2 & 0.2 & 0.2 & 0.2 \\
\hline \multirow[t]{3}{*}{ Regulatory quality } & Estimate & -0.7 & -0.7 & -0.8 & -0.9 & -0.9 \\
\hline & Percentile rank & 26.1 & 27.0 & 23.6 & 21.6 & 13.8 \\
\hline & Standard error & 0.2 & 0.2 & 0.2 & 0.2 & 0.2 \\
\hline
\end{tabular}




\section{Continued}

\begin{tabular}{|c|c|c|c|c|c|c|}
\hline \multirow[t]{3}{*}{ Rule of Law } & Estimate & -1.1 & -1.1 & -1.0 & -1.0 & -1.1 \\
\hline & Percentile rank & 10.3 & 12.2 & 13.5 & 15.9 & 13.9 \\
\hline & Standard error & 0.1 & 0.1 & 0.1 & 0.1 & 0.1 \\
\hline \multicolumn{7}{|l|}{ SENEGAL } \\
\hline \multirow[t]{3}{*}{ Control of corruption } & Estimate & -0.3 & -0.2 & 0.1 & 0.1 & 0.0 \\
\hline & Percentile rank & 49.8 & 53.6 & 58.2 & 59.1 & 57.2 \\
\hline & Standard error & 0.1 & 0.1 & 0.1 & 0.1 & 0.1 \\
\hline \multirow[t]{3}{*}{ Government effectiveness } & Estimate & -0.5 & -0.4 & -0.4 & -0.5 & -0.5 \\
\hline & Percentile rank & 39.3 & 40.8 & 40.4 & 38.5 & 36.5 \\
\hline & Standard error & 0.2 & 0.2 & 0.2 & 0.2 & 0.2 \\
\hline \multirow[t]{3}{*}{ Political stability } & Estimate & -0.1 & -0.1 & -0.2 & -0.1 & -0.3 \\
\hline & Percentile rank & 40.8 & 43.6 & 37.1 & 41.9 & 36.7 \\
\hline & Standard error & 0.2 & 0.2 & 0.2 & 0.2 & 0.2 \\
\hline \multirow[t]{3}{*}{ Regulatory quality } & Estimate & -0.1 & 0.0 & -0.2 & -0.2 & -0.1 \\
\hline & Percentile rank & 50.7 & 52.6 & 46.2 & 49.5 & 49.0 \\
\hline & Standard error & 0.2 & 0.2 & 0.2 & 0.2 & 0.2 \\
\hline \multirow[t]{3}{*}{ Rule of law } & Estimate & -0.3 & -0.2 & -0.1 & -0.1 & -0.2 \\
\hline & Percentile rank & 46.5 & 47.4 & 53.8 & 51.9 & 47.1 \\
\hline & Standard error & 0.1 & 0.1 & 0.1 & 0.1 & 0.1 \\
\hline \multicolumn{7}{|l|}{ TOGO } \\
\hline \multirow[t]{3}{*}{ Control of corruption } & Estimate & -0.3 & -0.2 & 0.1 & 0.1 & 0.0 \\
\hline & Percentile rank & 49.8 & 53.6 & 58.2 & 59.1 & 57.2 \\
\hline & Standard error & 0.1 & 0.1 & 0.1 & 0.1 & 0.1 \\
\hline \multirow[t]{3}{*}{ Government effectiveness } & Estimate & -0.5 & -0.4 & -0.4 & -0.5 & -0.5 \\
\hline & Percentile rank & 39.3 & 40.8 & 40.4 & 38.5 & 36.5 \\
\hline & Standard error & 0.2 & 0.2 & 0.2 & 0.2 & 0.2 \\
\hline \multirow[t]{3}{*}{ Political stability } & Estimate & -0.1 & -0.1 & -0.2 & -0.1 & -0.3 \\
\hline & Percentile rank & 40.8 & 43.6 & 37.1 & 41.9 & 36.7 \\
\hline & Standard error & 0.2 & 0.2 & 0.2 & 0.2 & 0.2 \\
\hline \multirow[t]{3}{*}{ Regulatory quality } & Estimate & -0.1 & 0.0 & -0.2 & -0.2 & -0.1 \\
\hline & Percentile rank & 50.7 & 52.6 & 46.2 & 49.5 & 49.0 \\
\hline & Standard error & 0.2 & 0.2 & 0.2 & 0.2 & 0.2 \\
\hline \multirow[t]{3}{*}{ Rule of law } & Estimate & -0.3 & -0.2 & -0.1 & -0.1 & -0.2 \\
\hline & Percentile rank & 46.5 & 47.5 & 53.8 & 51.9 & 47.1 \\
\hline & Standard error & 0.1 & 0.1 & 0.1 & 0.1 & 0.1 \\
\hline
\end{tabular}

Source: World Bank Development index. 
Table 13. Evaluation of governance index.

\begin{tabular}{|c|c|c|c|c|c|c|c|c|c|}
\hline \multirow{2}{*}{\begin{tabular}{|l} 
Indicator \\
$\begin{array}{c}\text { Control of } \\
\text { corruption }\end{array}$
\end{tabular}} & \multirow{2}{*}{$\begin{array}{l}\text { Country } \\
\text { Benin }\end{array}$} & \multicolumn{5}{|c|}{ Percentile rank (2012-2016) } & \multirow{2}{*}{$\begin{array}{l}\text { mean } \\
29.0\end{array}$} & \multirow{2}{*}{$\begin{array}{c}\text { variance } \\
39.9\end{array}$} & \multirow{2}{*}{$\begin{array}{c}\begin{array}{r}\text { Standard } \\
\text { deviation }\end{array} \\
6.3\end{array}$} \\
\hline & & 20.9 & 24.6 & 29.8 & 33.2 & 36.5 & & & \\
\hline & Cameroon & 10.6 & 13.0 & 10.6 & 13.0 & 11.1 & 11.7 & 1.5 & 1.2 \\
\hline & Congo Rep. & 10.4 & 10.9 & 10.1 & 10.6 & 9.6 & 10.3 & 0.2 & 0.5 \\
\hline & Cote d'Ivoire & 42.3 & 41.3 & 42.3 & 41.3 & 33.7 & 40.2 & 13.4 & 3.7 \\
\hline & Gabon & 28.4 & 29.4 & 28.4 & 26.4 & 24.5 & 27.4 & 3.9 & 2.0 \\
\hline & Ghana & 55.0 & 55.5 & 52.4 & 52.9 & 50.1 & 53.2 & 4.7 & 2.2 \\
\hline & Nigeria & 10.9 & 9.5 & 8.2 & 12.5 & 13.5 & 10.9 & 4.6 & 2.2 \\
\hline & Senegal & 49.8 & 53.6 & 58.2 & 59.1 & 57.2 & 55.6 & 14.8 & 3.8 \\
\hline & Togo & 49.8 & 53.6 & 58.2 & 59.1 & 57.2 & 55.6 & 14.8 & 3.8 \\
\hline \multirow{9}{*}{$\begin{array}{l}\text { Government } \\
\text { effectiveness }\end{array}$} & Benin & 36.5 & 37.0 & 36.1 & 29.8 & 33.2 & 34.5 & 9.1 & 3.0 \\
\hline & Cameroon & 21.6 & 21.6 & 21.6 & 21.6 & 22.1 & 21.7 & 0.1 & 0.2 \\
\hline & Congo Rep. & 11.4 & 12.8 & 14.4 & 14.9 & 12.0 & 13.1 & 2.3 & 1.5 \\
\hline & Cote d'Ivoire & 19.7 & 26.4 & 19.7 & 26.4 & 26.9 & 23.8 & 14.2 & 3.8 \\
\hline & Gabon & 19.4 & 22.3 & 26.9 & 23.6 & 20.7 & 22.6 & 8.4 & 2.9 \\
\hline & Ghana & 53.1 & 50.2 & 43.8 & 45.2 & 46.2 & 47.7 & 14.8 & 3.8 \\
\hline & Nigeria & 16.6 & 16.6 & 12.0 & 16.3 & 12.5 & 14.8 & 5.5 & 2.3 \\
\hline & Senegal & 39.3 & 40.8 & 40.4 & 38.5 & 36.5 & 39.1 & 2.9 & 1.7 \\
\hline & Togo & 39.3 & 40.8 & 40.4 & 38.5 & 36.5 & 39.1 & 2.9 & 1.7 \\
\hline \multirow[t]{9}{*}{ Political stability } & Benin & 58.3 & 58.3 & 47.1 & 45.2 & 48.6 & 51.5 & 40.0 & 6.3 \\
\hline & Cameroon & 26. & 27.5 & 12.4 & 15.2 & 14.8 & 19.2 & 49.2 & 7.0 \\
\hline & Congo Rep. & 31.3 & 29.9 & 31.0 & 26.7 & 25.2 & 28.8 & 7.4 & 2.7 \\
\hline & Cote d'Ivoire & 19.7 & 26.4 & 19.7 & 26.4 & 26.9 & 23.8 & 14.2 & 3.8 \\
\hline & Gabon & 56.9 & 58.8 & 51.9 & 47.6 & 43.8 & 51.8 & 39.2 & 6.3 \\
\hline & Ghana & 56.4 & 55.5 & 53.4 & 53.8 & 45.7 & 53.0 & 18.0 & 4.2 \\
\hline & Nigeria & 3.3 & 3.8 & 5.2 & 6.2 & 6.7 & 5.0 & 2.2 & 1.5 \\
\hline & Senegal & 40.8 & 43.6 & 37.1 & 41.9 & 36.7 & 40.0 & 9.1 & 3.0 \\
\hline & Togo & 40.8 & 43.6 & 37.1 & 41.9 & 36.7 & 40.0 & 9.1 & 3.0 \\
\hline \multirow[t]{8}{*}{ Regulator quality } & Benin & 38.9 & 37.4 & 31.3 & 30.8 & 30.3 & 33.7 & 16.6 & 4.1 \\
\hline & Cameroon & 21.3 & 19.0 & 19.7 & 16.8 & 23.1 & 20.0 & 5.7 & 2.4 \\
\hline & Congo Rep. & 8.1 & 8.1 & 9.6 & 10.1 & 10.2 & 9.2 & 1.1 & 1.0 \\
\hline & Cote d'Ivoire & 24.6 & 24.6 & 30.3 & 34.1 & 39.9 & 30.7 & 42.7 & 6.5 \\
\hline & Gabon & 30.8 & 28.9 & 26.0 & 25.0 & 21.6 & 26.5 & 12.7 & 3.6 \\
\hline & Ghana & 56.4 & 55.5 & 53.4 & 53.8 & 45.7 & 53.0 & 18.0 & 4.2 \\
\hline & Nigeria & 26.1 & 27.0 & 23.6 & 21.6 & 13.8 & 22.4 & 27.7 & 5.3 \\
\hline & Senegal & 50.7 & 52.6 & 46.2 & 49.5 & 49.0 & 49.6 & 5.5 & 2.4 \\
\hline
\end{tabular}




\section{Continued}

\begin{tabular}{cccccccccc}
\hline \multirow{3}{*}{ Rule of law } & Togo & 50.7 & 52.6 & 46.2 & 49.5 & 49.0 & 49.6 & 5.5 & 2.4 \\
& Benin & 33.3 & 34.3 & 36.1 & 33.7 & 29.3 & 33.3 & 6.2 & 2.5 \\
& Cameroon & 21.3 & 19.0 & 19.7 & 16.8 & 23.1 & 20.0 & 5.7 & 2.4 \\
& Congo Rep. & 12.7 & 11.5 & 13.0 & 14.4 & 12.7 & 12.9 & 1.1 & 1.0 \\
& Cote d'Ivoire & 14.6 & 19.7 & 32.7 & 30.8 & 28.4 & 25.2 & 60.1 & 7.8 \\
Gabon & 40.8 & 36.2 & 35.1 & 33.2 & 31.3 & 35.3 & 12.9 & 3.6 \\
Ghana & 55.9 & 58.2 & 60.1 & 60.6 & 54.8 & 57.9 & 6.5 & 2.5 \\
Nigeria & 10.3 & 12.2 & 13.5 & 15.9 & 13.9 & 13.2 & 4.3 & 2.1 \\
Senegal & 46.5 & 47.4 & 53.8 & 51.9 & 47.1 & 49.3 & 10.8 & 3.3 \\
Togo & 46.5 & 47.5 & 53.8 & 51.9 & 47.1 & 49.4 & 10.7 & 3.3
\end{tabular}

Source: Compiled V. Balla N. et al.

Table 14. Governance index final score (0.1 - 0.9).

\begin{tabular}{ccccccc}
\hline Country & Ps & Ge & Rq & RL & Cc & Total score \\
\hline Benin & 0.6 & 0.6 & 0.6 & 0.5 & 0.5 & 2.8 \\
Cameroon & 0.2 & 0.3 & 0.2 & 0.3 & 0.3 & 1.3 \\
Congo & 0.4 & 0.1 & 0.1 & 0.1 & 0.1 & 0.8 \\
Cote d'Ivoire & 0.3 & 0.5 & 0.5 & 0.4 & 0.6 & 2.3 \\
Gabon & 0.7 & 0.4 & 0.4 & 0.6 & 0.4 & 2.5 \\
Ghana & 0.8 & 0.8 & 0.8 & 0.8 & 0.7 & 3.9 \\
Nigeria & 0.1 & 0.2 & 0.3 & 0.2 & 0.2 & 1.2 \\
Senegal & 0.5 & 0.7 & 0.7 & 0.7 & 0.8 & 3.4 \\
Togo & 0.5 & 0.7 & 0.7 & 0.7 & 0.8 & 3.4 \\
\hline
\end{tabular}

Source: Compiled V. Balla N. et al.

Table 15. Container throughput.

\begin{tabular}{cccccccc}
\hline Port & 2010 & 2011 & 2012 & 2013 & 2014 & 2015 & 2016 \\
\hline Dakar & 349,231 & 369,137 & 383,903 & 428,171 & 384,376 & 486,092 & 496,800 \\
Lomé & 339,853 & 352,695 & 288,481 & 311,470 & 247,852 & 252,715 & 238,173 \\
Coutonou & 316,744 & 334,798 & 348,190 & 388,341 & 314,000 & 346,000 & 333,000 \\
Libreville & 356,285 & 442,802 & 505,000 & 550,000 & 619,692 & 571,000 & 550,000 \\
Pointe-Noire & 356,285 & 442,802 & 505,000 & 550,000 & 619,692 & 571,000 & 550,000 \\
Douala & 285,070 & 301,319 & 313,371 & 339,269 & 333,555 & 379,000 & 370,000 \\
Kribi & $\ldots$ & $\ldots$ & $\ldots$ & $\ldots$ & $\ldots$ & $\ldots$ & $\ldots$ \\
Lagos (Apapa) & $1,232,171$ & $1,559,276$ & $1,809,904$ & $1,696,000$ & $1,893,409$ & $1,558,679$ & $1,335,470$ \\
Tema & 642,519 & 813,494 & 884,984 & 894,362 & 756,578 & 816,852 & 925,964 \\
Abidjan & 639,265 & 664,488 & 880,104 & 772,296 & 803,317 & 697,160 & 705,000 \\
\hline
\end{tabular}

Source: World Bank Development index. 
Table 16. Port demand forecast.

\begin{tabular}{cccccccc}
\hline Port & 2017 & 2018 & 2019 & 2020 & 2021 & 2022 & 2023 \\
\hline Dakar & 516,828 & 547,416 & 579,815 & 614,132 & 650,480 & 688,978 & 729,756 \\
Lomé & 638,862 & 683,132 & 730,470 & 781,089 & 835,215 & 893,091 & 954,978 \\
Coutonou & 344,842 & 346,224 & 347,612 & 349,005 & 350,404 & 351,809 & 353,219 \\
Libreville & 675,300 & 725,715 & 7798,94 & 838,117 & 900,687 & 967,928 & $1,040,189$ \\
Pointe-Noire & 932,091 & $1,061,598$ & $1,209,098$ & $1,377,093$ & 1,568430 & $1,786,351$ & $2,034,551$ \\
Douala & 442,089 & 472,109 & 504,169 & 538,405 & 574,966 & 614,010 & 655,705 \\
Kribi & $\ldots$ & $\ldots$ & $\ldots$ & $\ldots$ & $\ldots$ & $\ldots$ & $\ldots$ \\
Lagos (Apapa) & $3,551,461$ & $4,184,801$ & $4,931,085$ & $5,810,456$ & $6,846,648$ & $8,067,625$ & $9,506,342$ \\
Tema & $1,337,046$ & $1,483,884$ & $1,646,848$ & $1,827,708$ & $2,028,432$ & $2,251,199$ & $2,498,431$ \\
Abidjan & 677,941 & 691,982 & 706,314 & 720,943 & 735,875 & 751,116 & 766,673 \\
\hline
\end{tabular}

Source: Compiled V. Balla N. et al.

Table 17. GPD of the countries (2016).

\begin{tabular}{ccc}
\hline Country & GDP (millions of us dollars) & World ranking \\
\hline Nigeria & 404,653 & 27 \\
Ghana & 42,739 & 85 \\
Cote d'ivoire & 36,373 & 90 \\
Cameroon & 32,217 & 93 \\
Senegal & 14,684 & 115 \\
Gabon & 14,214 & 117 \\
Benin & 8,583 & 137 \\
Congo, Rep & 7,834 & 141 \\
Togo & 4,400 & 155 \\
\hline
\end{tabular}

Source: World Bank Development index.

\section{(E) Time to import (days)}

One of the most important criteria's that are considered by shippers in port selection is the number of days required for importation. This is also an important factor to consider when evaluating a hub port. The importation time for the various countries is indicated in Table 18 and Figure 1.

\section{(F) Importation Cost}

Another factor to take into consideration is the costs involve importing a container at the various country' sports. The lower the cost of importation, the more likely it is for that port to attract a high traffic of goods. Table 19 and Figure 2 present the different importation cost.

The final scores from the evaluation of the different indices taken into consideration for all the ports are present in the Table 20.

The results presented above in Table 20 (Final evaluations scores for port hub status) show that among the west and Central African ports that were 


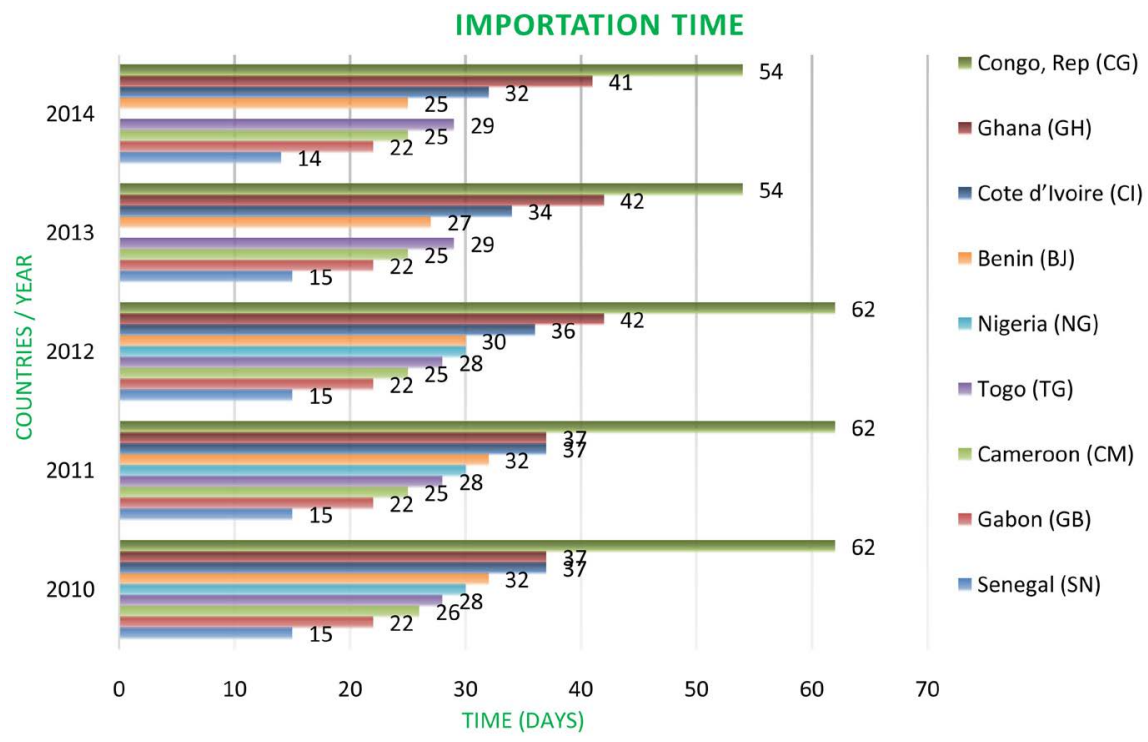

Figure 1. Importation time (days). Source: Compiled V. Balla N. et al.

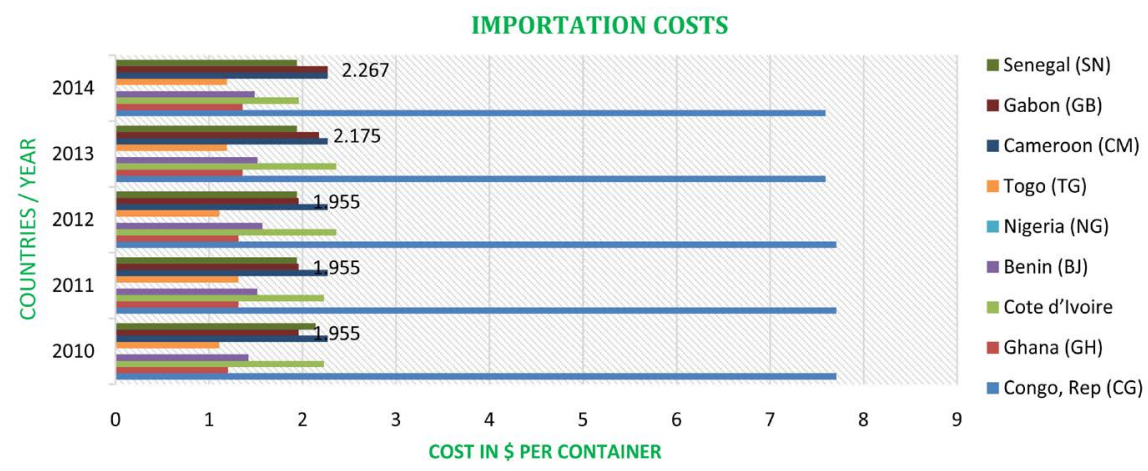

Figure 2. Importation cost. Source: Compiled V. Balla N. et al.

Table 18. Time to import (days) [13].

\begin{tabular}{cccccc}
\hline Country & 2010 & 2011 & 2012 & 2013 & 2014 \\
\hline Senegal (SN) & 15 & 15 & 15 & 15 & 14 \\
Gabon (GB) & 22 & 22 & 22 & 22 & 22 \\
Cameroon (CM) & 26 & 25 & 25 & 25 & 25 \\
Togo (TG) & 28 & 28 & 28 & 29 & 29 \\
Nigeria (NG) & 30 & 30 & 30 & 33.9 & 33.9 \\
Benin (BJ) & 32 & 32 & 30 & 27 & 25 \\
Cote d'Ivoire (CI) & 37 & 37 & 36 & 34 & 32 \\
Ghana (GH) & 37 & 37 & 42 & 42 & 41 \\
Congo, Rep (CG) & 62 & 62 & 62 & 54 & 54 \\
\hline
\end{tabular}

Source: World Bank Development data.

evaluated, the port with the highest score of 8.3. is Tema port. This means that Tema port is the most suitable port to serve as a hub port along the Gulf of Guinea. 
Table 19. Importation costs (\$ per container).

\begin{tabular}{|c|c|c|c|c|c|}
\hline Country & 2010 & 2011 & 2012 & 2013 & 2014 \\
\hline Congo, Rep (CG) & 7709 & 7709 & 7,709 & 7590 & 7590 \\
\hline Ghana (GH) & 1203 & 1315 & 1315 & 1360 & 1360 \\
\hline Cote d'Ivoire & 2227 & 2227 & 2360 & 2360 & 1960 \\
\hline Benin (BJ) & 1420 & 1516 & 1569 & 1520 & 1487 \\
\hline Nigeria (NG) & 1108.8 & 1108.8 & 1108.8 & 1959.5 & 1959.9 \\
\hline Togo (TG) & 1109 & 1315 & 1109 & 1190 & 1190 \\
\hline Cameroon (CM) & 2267 & 2267 & 2267 & 2267 & 2267 \\
\hline Gabon (GB) & 1955 & 1955 & 1955 & 2175 & 2267 \\
\hline Senegal (SN) & 2140 & 1940 & 1940 & 1940 & 1940 \\
\hline
\end{tabular}

Source: Compiled V. Balla N. et al.

Table 20. Final evaluations scores for port hub status.

\begin{tabular}{ccccccccccc}
\hline Index & Tema & Abidjan & Dakar & Lomé & Coutonou & Apapa & Douala & Kribi & Libreville & Pointe-noire \\
\hline Port classification & 0.5 & 0.4 & 0.2 & 0.4 & 0.4 & 0.4 & 0.3 & 0.5 & 0.3 & 0.5 \\
Port capacity & 1.1 & 0.8 & 0.9 & 0.3 & 0.4 & 0.2 & 0.6 & 0.1 & 0.7 & 1.4 \\
Governance & 3.8 & 2.3 & 3.4 & 3.4 & 2.9 & 1.2 & 1.8 & 1.8 & 2.5 & 0.8 \\
Demand forecast & 0.8 & 0.3 & 0.4 & 0.5 & 0.1 & 0.9 & 0.2 & $\ldots$ & 0.6 & 0.7 \\
GPD & 0.9 & 0.8 & 0.5 & 0.1 & 0.3 & 1 & 0.6 & 0.6 & 0.4 & 0.2 \\
Import time & 0.2 & 0.3 & 1 & 0.4 & 0.5 & 0.1 & 0.5 & 0.5 & 0.9 & 0.1 \\
Import cost & 0.9 & 0.5 & 0.7 & 1 & 0.8 & 0.6 & 0.2 & 0.2 & 0.2 & 0.1 \\
Total score & 8.3 & 5.4 & 7.1 & 6.1 & 5.4 & 4.4 & 4.5 & 3.7 & 5.6 & 3.8 \\
\hline
\end{tabular}

\section{Conclusion and Further Research}

The research was conducted with the aim of determining which port along the Gulf of Guinea can serve as a hub port for the West and Central African Region. Ten ports were considered for the evaluation among which included Dakar, $\mathrm{Ab}$ idjan, Tema, Lomé, Cotonou, Apapa, Doula, Kribi, Libreville and Pointe-Noire ports respectively. The method of evaluation was port indexing which takes into account port classification, port capacity, governance, demand forecast, GDP, import time and import cost. The final results showed that the port of Tema is the most suitable port to serve as a hub port. However, further research on more than one Hub status and their spokes, along Gulf of Guinea should be developed for both imports and exports.

\section{Conflicts of Interest}

The authors declare no conflicts of interest regarding the publication of this paper. 


\section{References}

[1] Dionisia, C.F. and Alga, D.F. The Impact of "Hub and Spokes" Port Networks on TransportSystems.

[2] Park, Y.-A. and Medda, F. (2015) Hub Status and Indexation of Container Ports.

[3] Talley, W. (2002) Dockworker Earnings, Containerization, and Shipping Regulation. Journal of Transport Policy, 36, 447-467.

[4] Nam, H. and Song, D. (2011) Defining Maritime Logistics Hub and Its Implication for Container Ports. Maritime Policy \& Management, 38, 269-292.

https://doi.org/10.1080/03088839.2011.572705

[5] Thill, J.C. and Lim, H. (2010) Intermodal Containerized Shipping in Foreign Trade and Regional Accessibility Advantages. Journal of Transport Geography, 530-547. https://doi.org/10.1016/j.jtrangeo.2010.03.010

[6] Cullinane, K. and Wang, Y. (2009) A Capacity-Based Measure of Container Port Accessibility. Journal of Logistics Research and Applications, 12, 103-117. https://doi.org/10.1080/13675560902749340

[7] Geurs, K.T. and Ritsema van Eck, J.R. (2001) Accessibility Measures: Review and Applications. National Institute of Public Health and the Environment, Bilthoven, RIVM Rapport 408505006.

[8] Wilson, A.G. (1971) A Family of Spatial Interaction Models, and Associated Developments. Environment and Planning, 3, 1-32.

[9] Martinez, F.J. (1995) Access: The Transport-Land Use Economic Link. Transportation Research B, 29, 457-470. https://doi.org/10.1016/0191-2615(95)00014-5

[10] Tongzon, J.L. (1995) Determinants of Port Performance and Efficiency. Transportation Research A, 29, 245-252.

[11] UNCTAD (1997) Review of Maritime Transport. United Nations Conference on Trade and Development, Geneva.

[12] Daniel, K., Aart, K. and Massimo, M. (2010) The World Wide Governance Indicators. Methodology and Analytical Issues.

[13] World Bank (2016) World Wide Governance Indicators. 